\title{
Enterprise pedagogy in music: an exploration of multiple pedagogies
}

Article

Accepted Version

Garnett, J. (2013) Enterprise pedagogy in music: an exploration of multiple pedagogies. Music Education Research, 15 (1). pp. 1-18. ISSN 1469-9893 doi:

https://doi.org/10.1080/14613808.2012.703175 Available at https://centaur.reading.ac.uk/29862/

It is advisable to refer to the publisher's version if you intend to cite from the work. See Guidance on citing.

To link to this article DOI: http://dx.doi.org/10.1080/14613808.2012.703175

Publisher: Taylor \& Francis

All outputs in CentAUR are protected by Intellectual Property Rights law, including copyright law. Copyright and IPR is retained by the creators or other copyright holders. Terms and conditions for use of this material are defined in the End User Agreement.

\section{www.reading.ac.uk/centaur}

\section{CentAUR}

Central Archive at the University of Reading

Reading's research outputs online 


\title{
Enterprise pedagogy in music: An exploration of multiple pedagogies
}

Dr James Garnett, Institute of Education, University of Reading ${ }^{1}$

\begin{abstract}
This article investigates the nature of enterprise pedagogy in music. It presents the results of a research project that applied the practices of enterprise learning developed in the postcompulsory music curriculum in England to the teaching of the National Curriculum for music for 11-to-14-year-olds. In doing so, the article explores the nature of enterprise learning and the nature of pedagogy, in order to consider whether enterprise pedagogy offers an effective way to teach the National Curriculum. Enterprise pedagogy was found to have a positive effect on the motivation of students and on the potential to match learning to the needs of students of different abilities. Crucially, it was found that, to be effective, not only did the teacher's practice need to be congruent with the beliefs and theories on which it rests, but that the students also needed to share in these underlying assumptions through their learning. The study has implications for the way in which teachers work multiple pedagogies in the process of developing their pedagogical identity.
\end{abstract}

\section{Key words}

Enterprise, pedagogy, informal, formal, nonformal, motivation, key stage 3, National curriculum

\section{Enterprise learning}

Enterprise learning emerged in the 1980s from the active learning and experiential learning approaches of the 1960s and 70s (Harris 1995). It is to be distinguished from training for entrepreneurship, which involves acquiring the specific skills needed to start and develop a small business. Enterprise learning is concerned with the personal skills, behaviours and attributes that characterise entrepreneurs, but seeks to apply these to a wide range of life experiences that an enterprising individual might encounter (Jones \& Iredale 2010). A range of definitions and typologies of enterprise exists in the literature (see for example Shuttleworth 1993), but a succinct statement that captures the common features is provided by Johnson 1998. He describes an enterprising individual as someone with a high need for achievement, a high need for autonomy, an internal locus of control (ie able to be selfdirecting) an ability to take calculated risks, and possessing innovativeness and creativity.

Enterprise education has an established place within the post-compulsory 14-19 music curriculum in England through the BTEC (Business and Technology Education Council) and Creative and Media Diploma qualifications. The BTEC is a vocational qualification that is offered in a wide range of subjects, including a number that are related specifically to music

\footnotetext{
${ }^{1}$ Email: j.s.garnett@reading.ac.uk
} 
(including music, performing arts, music performance and music production). The Creative and Media Diploma was one of a suite of new qualifications introduced in 2008 with a view to integrating academic and vocational learning and securing employer involvement in the education of 14-to-19 year olds.

Although different qualifications, the approaches to learning promoted by the BTEC and the Creative and Media Diploma qualifications share common characteristics. Teachers develop schemes of work that require students to produce a specified musical outcome, to be presented either live or as a recording. Although students are given a brief, there is generally some input from students as to the precise nature of the outcome following research that might encompass relevant musical practices, repertoires and audiences depending on the nature of the project. Students often work collaboratively on an outcome, but will have a role that enables them to identify their distinct contribution. The process of preparing for the outcome is an essential part of the learning: students find out how they will go about the work and record the process of planning, which is monitored by means of milestone assessment points. The process of evaluating the outcome and the response of an audience also forms part of the learning. Assessment captures evidence from the process as well as the product, and may include aspects of a student's work in planning and evaluation. Assessment may also include non-musical attributes such as the ability to cooperate and the ability to respond to direction. (Edexcel 2007, 2010)

Enterprise learning already features in the compulsory 11-16 National Curriculum as one of seven cross-curricular dimensions (reflecting the role of Initiative and Entrepreneurship identified by the European Reference Framework relating to lifelong learning - European Parliament 2006). An enterprising approach to teaching and learning is defined in the National Curriculum in terms of four characteristics. It involves learning by doing, through problem-solving activities, working as a team and with the teacher providing facilitation rather than instruction (DCSF 2010). In addition, the National Curriculum for Music for students aged 11 to 14 identifies several specific opportunities for enterprise learning. These include performance (on instruments and using technology) in a range of contexts within and beyond the classroom, taking on different roles and responsibilities including developing music leadership skills, learning about the music industry and intellectual property rights, and opportunities to work with a range of musicians from professional and community arts organisations as well as peers (DCSF 2007).

What this research aimed to do was to apply the practices of enterprise learning that are wellestablished within the 14-19 music curriculum to the compulsory 11-14 National Curriculum. In doing so it was building on Lucy Green's work in applying the informal learning of popular musicians to the National Curriculum (Green 2008).

\section{Pedagogy}

If enterprise learning involves students developing the characteristics of an enterprising individual, enterprise pedagogy is an approach to teaching that creates the conditions for students to develop these attributes and to apply them to learning in subjects across the 
curriculum. Before considering in detail what the characteristics of enterprise pedagogy might be, and how they might apply to music, a wider ranging discussion on the nature of pedagogy is necessary.

Pedagogy is a word that is understood differently in different parts of the world. In AngloAmerican thinking, pedagogy is often connected with teaching method and is distinct from (and subordinate to) the curriculum, whereas in Europe, the term "didactics" is more frequently used in connection with teaching method, pedagogy having a wider implication that includes both curriculum and didactics (Alexander 2001). Moore (2000) considers that "the separation of curriculum and pedagogy, like the separation of language and thought, may have some convenience value for analytical purposes, but will always remain somewhat artificial in practice" (p150). While recognising this relationship, Green (2008) nevertheless distinguishes the content of the curriculum from the method by which it is taught, establishing the possibility of teaching the same curriculum through different approaches to pedagogy (for example, informal or formal). Enterprise pedagogy can thus be identified as an approach to teaching that is distinct from an enterprise curriculum, and which can be applied to the music curriculum in the same way that informal or nonformal approaches can be.

Alexander (2008) defines pedagogy as the act of teaching, together with the ideas, values and beliefs by which that act is informed, sustained and justified. Crucially, this definition connects the practice of teaching with the thinking that informs it, recognising that what the teacher knows and thinks shapes how he or she acts (Alexander 2010). This conjunction of theory and practice recognises that practice is not self-sufficient and cannot be considered in isolation. It suggests that what teachers do arises from underlying theories and beliefs that can be inferred from their actions even if teachers are not consciously aware of them. Thus Moore (2000) for example considers an awareness of the theories that are implicit a teacher's action to be an important element in their developing pedagogy.

Whilst pedagogy is not the same as the practice of teaching, neither is it the same thing as theory. Pedagogy seeks to make explicit the values and ideas that inform what a teacher does, in order to make sense of observable practice (Alexander 2008). Theory demands consistency and a principled derivation of classroom practice from axioms to do with the nature of knowledge and the nature of learning - Gordon's Learning Sequences in Music (1989) and Elliot's Music Matters ( 1995 ) for example present theories of musical learning. The concept of pedagogy, by contrast, recognises that a teacher's practice may be informed by a variety of theories and values that are not necessarily consistent with one another and which come into play according to the circumstances in the classroom. It is therefore possible to conceive of teachers adopting multiple pedagogies in a way that they could not adhere concurrently to multiple theories. Theories, by virtue of their axiomatic foundations and their principled derivation, lay claim to truth in a way that pedagogy does not. Pedagogies, with their roots in practice, enable teachers, at different times, to adopt practices with potentially contradictory theoretical implications in order to deal with particular students in particular circumstances (Loughran 2010). 
Whilst a theory of music education claims its authority on the basis of its truth, a pedagogy (among multiple other pedagogies) can be seen to claim its authority on the basis of its effectiveness. This is a much more contingent claim: it suggests that teachers will select one pedagogical approach in preference to another because they believe it to be better suited to a particular set of circumstances. This raises the crucial question of how they make this decision: what makes a pedagogy effective? Three factors will be considered below.

First, by choosing to adopt one of a number of possible pedagogies, teachers are choosing to use a set of classroom practices, but in doing so we have seen that they are also choosing the underlying theories and values that are implied by those practices. (Teachers choosing informal pedagogy will also be choosing a theory of learning that promotes self-directed learning by students over instruction, for example.) The effectiveness of the teaching will therefore depend to some extent on the extent to which the practices are congruent with the underlying theories. If the practice and theories are not congruent, the teaching will not be effective. Thus, Harris (1995), in an observation-based study of enterprise pedagogy among four teachers, found that the reality of their teaching did not always match their declared aims. He observed practical tasks that looked like active and experiential learning opportunities, but which often turned out to have minimal intellectual challenge and to involve little more than routine fact-finding. Real pupil choice was rare, and much of what was presented as problem solving was in fact teacher-led and teacher-defined. The practices of enterprise pedagogy did not achieve the intended results because the teachers had not fully absorbed the principles of enquiry-based learning on which they rested.

Second, if teachers select a particular pedagogy to achieve a particular goal, it will be judged effective to the extent that it achieves that goal. This implies that, sitting above the theories and beliefs that inform practice, is a higher-order set of values that influences the aims of teaching (related to what Bernstein (1996) describes as pedagogical identity). The interaction between these values and the contingencies of classroom pedagogy would make an interesting study, but is beyond the scope of this article. For the purpose of this research, the assumption was made that the goal of effective teaching was to develop students' musical understanding in accordance with the English National Curriculum.

Third, in relation to this particular goal, an effective pedagogy can be identified as one that successfully enables students to develop their musical understanding. Whilst theoretically appealing, this definition is, unfortunately, of limited use in practice, because of the timescale over which musical understanding develops. Musical learning is not a linear process, and periods of deterioration form part of the cycle of learning (Fautley 2010, Green 2008). Therefore teachers cannot necessarily judge the effectiveness of a pedagogy that has been adopted as a contingent strategy solely in terms of the learning outcomes: positive results might take longer to manifest themselves. This is perhaps why engagement and motivation are such important features of Green's work. Based on broadly constructivist principles, informal pedagogy requires students to be active and willing participants in their learning, because it is only they who can enact the cognitive processes involved in connecting new experiences with their prior learning, transforming them into understanding (Black 2001). To be considered effective, a pedagogy based on constructivist principles must therefore at least 
be successful in engaging students and motivating them to learn. The ability to motivate students is thus a key indicator of effectiveness for a pedagogy, particularly in the short term. Whilst necessary, this is not however a sufficient condition for effectiveness, because it would be possible for students to be engaged and having fun without actually learning anything. (Indeed, Ofsted's evaluation of the application of Green's work in the Musical Futures was more positive about engagement than about musical progress - Ofsted 2006.)

\section{Enterprise pedagogy}

Enterprise pedagogy can be considered as the collection of practices and theories of teaching that fosters enterprise learning, just as (for example) informal pedagogy represents the approach to teaching that promotes informal learning. This section will consider what these theories and practices are.

Five key characteristics emerge from the literature in connection with the practice of teachers in promoting enterprise learning. Teachers organise their teaching so that students learn by doing, by asking questions, by taking control of a task. They are given freedom in relation to the means by which an agreed outcome is achieved. This requires teachers to give students responsibility for their own learning, so that they identify what they need to learn in order to achieve the outcome. Enterprise teaching promotes teamwork, fostering a collaborative ethos in which students take on different roles in a group according to the requirements of the task and their own abilities. Finally, the role of the teacher becomes focused on the process of learning rather than the content. The teacher acts as a facilitator, allowing students the opportunity to think and act independently (Johnson 1998, Harris 1995, Jones \& Iredale 2010). Taken together with the characteristics of enterprise learning discussed earlier, and applied to the context of the 11-14 music curriculum, these practices can be summarised as shown in Table 1.

\begin{tabular}{|l|l|}
\hline The Teacher... & The Students... \\
\hline $\begin{array}{l}\text { Sets a brief that requires students to } \\
\text { create a real piece of music for a } \\
\text { real purpose }\end{array}$ & $\begin{array}{l}\text { Research the brief - what it requires and how } \\
\text { musicians have responded to similar briefs - in order to } \\
\text { work out how they will respond musically to the } \\
\text { specified function and context. }\end{array}$ \\
\hline $\begin{array}{l}\text { Encourages students to be } \\
\text { imaginative in creating their own } \\
\text { response to the brief }\end{array}$ & $\begin{array}{l}\text { Are required to be creative both in a problem-solving } \\
\text { sense of working out what is required to meet the brief, } \\
\text { and in the sense of musical creativity. }\end{array}$ \\
\hline $\begin{array}{l}\text { Puts students in control of their } \\
\text { own work }\end{array}$ & $\begin{array}{l}\text { Manage the process of responding to the brief, } \\
\text { planning their use of time, resources and people in } \\
\text { order to meet a deadline. }\end{array}$ \\
\hline $\begin{array}{l}\text { Allows students to make mistakes, } \\
\text { accepting the risk that students will } \\
\text { get things wrong rather than } \\
\text { guiding them towards a } \\
\text { preconceived solution }\end{array}$ & $\begin{array}{l}\text { Try things that won't necessarily work. Both in relation } \\
\text { to the creative response to the brief and to the } \\
\text { management of the task there are elements of } \\
\text { uncertainty that students need to address and respond } \\
\text { to. }\end{array}$ \\
\hline $\begin{array}{l}\text { Facilitates learning, supporting } \\
\text { students in working out what they } \\
\text { need to learn }\end{array}$ & $\begin{array}{l}\text { Take responsibility for their learning. Having worked } \\
\text { out how they are going to meet the brief, the students } \\
\text { also need to work out what they need to learn to }\end{array}$ \\
\hline
\end{tabular}




\begin{tabular}{|l|l|}
\hline & achieve this and seek out teaching when necessary. \\
\hline $\begin{array}{l}\text { Guides students towards } \\
\text { considering the different roles } \\
\text { required to meet the brief and who } \\
\text { in their group is best suited to each } \\
\text { role }\end{array}$ & $\begin{array}{l}\text { Take on different roles according to their interests and } \\
\text { strengths. This has the result that, potentially, different } \\
\text { students will learn different things. }\end{array}$ \\
\hline
\end{tabular}

Table 1

The practices of enterprise pedagogy have implicit roots in three, interconnected collections of theories. The pedagogy is firmly student-centred, encouraging students to work collaboratively with each other, independently of the teacher, so that students are active in generating their own understanding (Johnson 1988). This suggests a theory of learning founded in social constructivism, the learning of an individual student arising from, and in turn shaping the learning of others in the group in relation to a specific context (Black 2001), which (in the case of enterprise pedagogy) is defined by the brief. Of particular importance is the role of the student as the agent of learning. As noted above in connection with constructivist theory, learning involves the student actively in deriving understanding from his or her experiences by connecting these experiences with prior learning. Social constructivism accentuates the social and contextual nature of this understanding and highlights the importance of a student's ability to work independently, directing their own interaction with peers and teacher alike.

The second area of theory on which enterprise pedagogy rests is to some extent implicit in social constructivism, but is nevertheless a defining feature of enterprise, and that is to do with the relevance of learning to the world of work (Shuttleworth 1993). This seeks to connect what students learn in school with its application in "real life". Lave and Wenger (1991) provide insight into relevancy through their analysis of situated learning. By situating learning within the social context of work, they see students as participating, albeit at the periphery, in a community of practice that introduces them to the relational nature of knowledge and learning alongside the cognitive. This legitimate peripheral participation (as they describe it) involves learning through the generalising of social practice as well as conceptual aspects of experience. In the context of this study, it involves learning something of what it means to be a musician alongside learning music.

The third theory that is implicit in enterprise pedagogy for music specifically concerns the student's musical experience and its authenticity. Although a range of authors have discussed authentic situations for learning in a variety of contexts, this connects directly with what Keith Swanwick described as the "first principle" of musical learning: care for music as discourse (Swanwick 1999). To experience their work as music, Swanwick argued, students need to experience that layer of musical meaning he described as "expression". This is what transforms a collection of pitches and rhythms into a virtual reality that has a shape and a character of its own, and is an important factor in contributing to the "reality" of what students experience in responding to a brief in the context of enterprise pedagogy. 


\section{Method}

This review of the literature gives rise to three questions connected with the effectiveness of enterprise pedagogy in delivery the11-14 National Curriculum:

1. To what extent did enterprise pedagogy motivate students to learn?

2. What impact did enterprise pedagogy have on learning outcomes?

3. To what extent were teachers able to implement practices promoting enterprise learning that were congruent with underlying theories of learning?

In order to investigate these questions, teachers at schools local to the University of Reading were invited to participate in an action research project in which they would develop a scheme of work that employed enterprise pedagogy. Teachers at three schools volunteered to take part, each school having an existing programme of post-14 vocational qualifications, and each teacher having a professional interest in developing their own practice in relation to 1114-year-old students.

More than one school was asked to participate in the study in order to explore different ways in which enterprise pedagogy could be introduced into the curriculum. This made it possible to draw conclusions about the pedagogical approach rather than its manifestation in a particular scheme of work (which would have been the case had just one school been studied). The teachers met twice with the principal investigator at the outset of the study to plan the project and to develop a shared understanding of enterprise pedagogy, based on a review of the literature and previous experience. It was agreed that each teacher would write a different scheme of work, based on the circumstances of their school and the prior learning of their students. The scheme of work would be targeted at Year 9 students (ages 13-14), requiring them to fulfil a set brief over a period of approximately $6-8$ weeks during the Autumn of 2010.

This research was conceived of as action research in which teachers were "constructing their own knowledge" (Cain 2008, p 284). It was concerned with the teachers investigating the effect of enterprise pedagogy on their own practice within the context of their own school, the principal investigator playing a role that supported and co-ordinated the three projects and their evaluation. This approach recognised on the one hand that the intervention was highly context-dependent, so that the impact of enterprise pedagogy would be influenced by a host of variables that could not be controlled, for example, the previous music lessons experienced by the students. (McNiff 1988). On the other hand, it recognised that the teachers were active participants in the success or otherwise of enterprise pedagogy; they had an interest in making the hypothesis come true (Schön 1983). The research thus belongs to a tradition of research in music education that develops experiential, practical and presentational knowledge even if it does not meet the more rigorous conditions for propositional knowledge (Cain 2010).

In staking any claim to knowledge, this action research aimed to achieve what Pring (2004) describes as formalised reflection by means of the systematic evaluation of teaching. A survey of all the students involved was administered at the end of the project in order to add 
to the teachers' understanding of how the students responded to the project. Whilst the limitations of a questionnaire were recognised (particularly in relation to whether the students would interpret the questions in the way that was intended), it was felt that the opportunity for every student to provide anonymous feedback would provide a valuable counter-balance to the teachers' own perceptions of the students' reactions to the project. In addition to gathering quantitative data on the students' perceptions of their motivation and learning, school assessment data was gathered, which included a grade for the project as well as a grade for the scheme of work prior to the project in order that a comparison could be made. The teachers were asked to keep a reflective diary of their work with the classes involved with the project. These, together with an analysis of the questionnaires, informed a semistructured interview with each teacher after the project. The interviews served to clarify the context for the quantitative data, to explore the teachers' experiences and own evaluation of the project and to prompt their reactions to varying experiences at the different schools.

In addition to the teachers' informed consent, permission was gained from students and parents (as well as from headteachers) for the use of attainment data as well as for completion of the questionnaires. Although the students had to participate in the scheme of work as part of their music curriculum, inclusion in the data sample for analysis was voluntary.

\section{Results}

The schemes of work that were designed by the three teachers as vehicles for exploring enterprise pedagogy are summarised in Tables 2, 3 and 4. These are followed by a summary of the results from the questionnaire and then an analysis of the assessment data from the schools. The qualitative data from the teacher interviews and diaries will be presented within the Analysis section that follows in order to contextualise and interpret the quantitative results.

\section{School A}

Students in two classes were commissioned to prepare a short promotional film featuring the new school buildings that could be shown to parents at the annual Open Evening. The film would combine still photographic images with music. The Headteacher and Governors were the clients for this project and would select which films were to be shown.

At the start of the project, students watched examples of promotional films on You Tube, evaluating the use of music and developing their understanding of what was implied by the brief. As a whole class, they defined the success criteria, identified the roles that were required in a team for this project, then formed themselves into groups of between 3 and 6 students, auditing their skills and allocating roles accordingly.

Subsequent lessons were spent working in these groups to plan and make their film, students using their mobile phones to take the pictures they needed. Some groups developed their music acoustically, recording it and adding it to images using Imovie software; others used Garage Band software to compose their music. After the initial input on the brief and on how to use the software, the class teacher left the management of the project to the groups of students. He prompted planning and target setting, responded to requests for instruction in 
particular skills and intervened if necessary to support students.

Table 2

\section{School B}

The music teacher decided that her Year 12 tutor group would work in partnership with a challenging Year 9 class to produce a Christmas CD that they would sell in aid of a local charity.

The role of the Year 9 class was to manage the production of the $\mathrm{CD}$, not just the recording of the music to be included on it. The initial lesson was spent planning the content of the CD, after which students worked in groups to prepare individual tracks. One group of students worked on artwork for the CD cover. Other students wrote to members of staff who were known to have an interest in music, and several staff recorded tracks, as did the Year 12 tutor group. Midway through the project there was a vocal workshop for the whole class which resulted in a whole-class performance that was recorded for the CD.

Initial enthusiasm for the project was dampened when some students realised that they were unable to work on the tracks they had hoped to record because the music was still in copyright (I'm dreaming of a white Christmas was a case in point). Nevertheless, the CD was completed and, with the aid of publicity from the Year 12 tutor group, sold well around the school.

\section{Table 3}

\section{School C}

The teacher rewrote an existing scheme of work on minimalism. Instead of teaching this in the context of $20^{\text {th }}$ Century music, she gave students the brief of composing music for a computer game using techniques derived from the music of Steve Reich. Students developed a storyboard for their own computer game, identifying characters and levels of the game that the music was required to accompany.

The first lesson was devoted to listening to music from computer games, analysing and evaluating it in order that students understood the brief. Students worked in groups of four, and were encouraged to take on different roles within the group, although many chose to take part in all the work. At the end of each lesson, the teacher prompted the whole class to review their progress and set targets for the following week. Otherwise, the students worked independently, calling on the teacher to provide input when required.

\section{Table 4}

Results from the questionnaire that students completed at the end of the scheme of work are summarised in tables $4-7$ below. Two classes were involved at School A (N=42), one at School B $(\mathrm{N}=22)$ and one at School C $(\mathrm{N}=25)$.

\begin{tabular}{|l|l|l|l|l|}
\hline Question & Response & $\begin{array}{l}\text { School } \\
\text { A }\end{array}$ & School B & $\begin{array}{l}\text { School } \\
\text { C }\end{array}$ \\
\hline 1. I am pleased with what my group achieved & I agree & $87 \%$ & $75 \%$ & $87 \%$ \\
\hline $\begin{array}{l}\text { 2. I am pleased with my contribution to the } \\
\text { group }\end{array}$ & I agree & $97 \%$ & $89 \%$ & $91 \%$ \\
\hline
\end{tabular}


Table 5

\begin{tabular}{|c|c|c|c|c|}
\hline Question & Response & $\begin{array}{l}\text { School } \\
\text { A }\end{array}$ & School B & $\begin{array}{l}\text { School } \\
\text { C }\end{array}$ \\
\hline \multirow{2}{*}{$\begin{array}{l}\text { 3. We produced a real piece of music } \\
\text { for a real purpose }\end{array}$} & I agree & $88 \%$ & $95 \%$ & $83 \%$ \\
\hline & $\begin{array}{l}\text { This motivated } \\
\text { me }\end{array}$ & $69 \%$ & $60 \%$ & $88 \%$ \\
\hline \multirow{2}{*}{ 4. We had to be creative } & I agree & $100 \%$ & $77 \%$ & $100 \%$ \\
\hline & $\begin{array}{l}\text { This motivated } \\
\text { me }\end{array}$ & $87 \%$ & $64 \%$ & $92 \%$ \\
\hline \multirow{2}{*}{$\begin{array}{l}\text { 5. We were put in control of our own } \\
\text { work }\end{array}$} & I agree & $90 \%$ & $59 \%$ & $96 \%$ \\
\hline & $\begin{array}{l}\text { This motivated } \\
\text { me }\end{array}$ & $84 \%$ & $48 \%$ & $87 \%$ \\
\hline \multirow[t]{2}{*}{ 6. Sometimes we got things wrong } & I agree & $81 \%$ & $91 \%$ & $100 \%$ \\
\hline & $\begin{array}{l}\text { This motivated } \\
\text { me }\end{array}$ & $54 \%$ & $27 \%$ & $75 \%$ \\
\hline \multirow{2}{*}{$\begin{array}{l}\text { 7. I had to work out what I needed to } \\
\text { learn to complete the task }\end{array}$} & I agree & $79 \%$ & $45 \%$ & $96 \%$ \\
\hline & $\begin{array}{l}\text { This motivated } \\
\text { me }\end{array}$ & $67 \%$ & $27 \%$ & $82 \%$ \\
\hline \multirow{2}{*}{$\begin{array}{l}\text { 8. Different people in our group had } \\
\text { different roles }\end{array}$} & I agree & $86 \%$ & $77 \%$ & $100 \%$ \\
\hline & $\begin{array}{l}\text { This motivated } \\
\text { me }\end{array}$ & $77 \%$ & $45 \%$ & $91 \%$ \\
\hline
\end{tabular}

Table 6

9. What helped you to learn? Put the following items in order: 1 is the most important, 6 the least.

\begin{tabular}{|c|c|c|c|}
\hline & $\begin{array}{c}\text { School } \\
\text { A }\end{array}$ & School B & $\begin{array}{l}\text { School } \\
\text { C }\end{array}$ \\
\hline & $\begin{array}{c}\% \text { in top } \\
3 \\
\text { [order] }\end{array}$ & $\begin{array}{c}\text { \% in top } \\
3 \\
\text { [order] }\end{array}$ & $\begin{array}{c}\text { \% in top } \\
3 \\
\text { [order] }\end{array}$ \\
\hline a) We produced a real piece of music for a real purpose & $74[2]$ & $76[1]$ & $50[4]$ \\
\hline b) We had to be creative & $86[1]$ & $67[2]$ & $63[=2]$ \\
\hline c) Sometimes we got things wrong & $24[5]$ & $38[5]$ & $46[5]$ \\
\hline d) We were put in control of our work & 69 [3] & $43[=3]$ & $63[=2]$ \\
\hline e) Different people in our group had different roles & $33[4]$ & $43[=3]$ & $33[6]$ \\
\hline $\begin{array}{l}\text { f) I had to work out what I needed to learn to complete the } \\
\text { task }\end{array}$ & $19[6]$ & $19[6]$ & $64[1]$ \\
\hline
\end{tabular}

(The percentage relates to the number of students ranking each factor in the top three. The number in square brackets shows the ranking of these percentages.)

Table 7

All three schools gave each student a grade at the end of every scheme of work. Table 8 compares the grade attained by students in this study with their grade in the previous scheme of work. All three schools used a grading system based on the National Curriculum Levels. These Levels provide a structure within the National Curriculum (separately for each subject in the curriculum) that describes progression in students' attainment throughout their school 
career in terms of a nine-point scale. Most students are expected to attain Level 4 at the age of 11 and Level 5 or 6 at the age of 14, with scope for the most able to attain Level 8 or the Exceptional Performance level. In practice, some schools use the Levels as a grading system to track progress between the ages of 11 and 14, subdividing the stages of development between Levels in order to do so. All three schools in this study subdivided each level into three, so that students would progress, for example, from Level $4 a$ through $4 b$ and $4 c$ to Level 5. (For a discussion of the implications of this practice and how it departs from the intended application of the Levels, see Fautley 2010.) Table 8 shows the number of these sublevels by which students' grade increased or decreased at the end of this project compared with the previous scheme of work. Schools B and C applied this grading system to each piece of work. School A, by contrast, applied it to the student, so that the grade reflected their stage of development as evinced by work in the current project. School A took the view that students' grades could not regress once they had shown themselves capable of working at a particular level. This is why there are no students at School A who attained a lower grade in this project than in the previous one; whereas it was possible at Schools B and C for this piece of work to be graded lower than the previous piece of work.

\begin{tabular}{|c|c|c|c|}
\hline $\begin{array}{c}\text { Difference in grades } \\
\text { compared with } \\
\text { previous project }\end{array}$ & $\begin{array}{c}\text { School A } \\
\text { (49 students) }\end{array}$ & $\begin{array}{c}\text { School B } \\
\text { (31 students) }\end{array}$ & $\begin{array}{c}\text { School C } \\
\text { (19 students) }\end{array}$ \\
\hline+7 & & & 3 \\
\hline+6 & & & 1 \\
\hline+5 & & 1 & 2 \\
\hline+4 & 1 & 1 & 4 \\
\hline+3 & 28 & 8 & 1 \\
\hline+2 & 20 & 12 & 4 \\
\hline+1 & & 4 & 2 \\
\hline 0 & & 1 & 2 \\
\hline-1 & & & \\
\hline-2 & & 1 & \\
\hline-3 & & & \\
\hline-4 & & & \\
\hline-5 & & & \\
\hline-6 & & & \\
\hline
\end{tabular}

Table 8

\section{Analysis}

The teachers at Schools A and C both perceived there to have been a positive response from their students in terms of motivation and learning, and they both valued the relationship that their facilitating role enabled them to develop with their students. Both indicated that they intended to build on their experience of the project by adopting this approach again. The teacher at School B did not have such a positive experience. Whilst a CD was successfully produced and sold, the students did not respond to the creative opportunities offered by the brief in the way that she had anticipated, and she had felt obliged to take a more directive role than she had wished. (The reasons for this will be explored in more detail below.) 
Nevertheless, the teacher at School B felt that enterprise pedagogy did have something useful to offer; and, having learned from this project, she was intending to try it again.

These perceptions of the teachers are supported by the views expressed by the students through the questionnaires. Responses to questions 1 and 2 (Table 5) indicate that most were pleased with what they achieved, but less so at School B. Levels of motivation reported by students in connection with each of the factors identified in questions 3 to 8 (Table 6) generally demonstrate a positive response in Schools $\mathrm{A}$ and $\mathrm{C}$ and a significantly less positive response in School B.

A more nuanced understanding can be gained by analysing each of the six features of enterprise pedagogy in turn. This will draw attention to issues that will make it possible to answer the three research questions in the conclusion to this article.

\section{We produced a real piece of music for a real purpose}

There was strong agreement among students from all three schools that this had, indeed, been their experience (Table 6). This indicates that the teachers had succeeded in communicating the ethos of enterprise, and were not seen as simply dressing up a normal classroom task in new clothing. At Schools $\mathrm{A}$ and $\mathrm{C}$ a high proportion of students found the reality of the brief to be motivating. School B stands out because it had the highest number of students registering the "reality" of the task (producing the $\mathrm{CD}$ ) but the lowest number being motivated by this. Drawing on the response of students in lessons, their teacher offered two explanations of this. One was the incredulity expressed by students when they were told that they were to produce a CD. The teacher's impression was that the class did not believe that they would actually achieve this until most of the tracks were recorded. The other was the students' response to the issue of copyright. On finding that they would not able to record and sell their first choice of song because it was in copyright, several students lost interest in the project. School C is also interesting, because the greatest number of students were motivated by the reality of the brief, even though the brief itself was the least "real" of the three. The teacher reported that students enjoyed working on music for computer games because it related to something that they did at home, even if the music they were writing would not actually be used in a computer game. Students at School C also rated the reality of the brief as a less important factor in their learning than other factors (this was ranked fourth in Table 7, whereas it was in the top two at Schools A and B), suggesting that factors to do with the way the brief was implemented were more important. In summary, the reality of the brief was an important motivating factor, but its relevance to the students and its credibility were also important, as was the way in which it was used.

\section{We had to be creative}

All students at School A and School C felt that they had to be creative, as did most at School B. The majority were motivated by this (Table 6) and a high proportion felt that this contributed strongly to their learning (Table 7). Teachers at all three schools remarked on the way in which the more able students in particular responded very positively to the freedom to be creative. They described the sense in which able students were 'allowed to fly' and were 
not held back by learning sequences or specific outcomes that had been prescribed by the teacher. This is reflected in the distribution of grades (Table 8) compared with the previous project undertaken by the classes. There is a marked jump in attainment amongst the more able at both Schools B and C. (This was less noticeable at School A, as a result of the different marking system described above.) There is perhaps an ambiguity in this question in that it does not distinguish between musical creativity and the creativity that was required of students in deciding how to respond to the brief. Nevertheless, the positive response from so many of the students again suggests that the ethos of enterprise learning was successfully communicated in all three schools.

\section{We were put in control of our own work}

A high proportion of students at School A and School C felt that they were put in control of their own work and were motivated by this (Table 6). Many at School C also felt that this made a strong contribution to their learning (Table 7). This was a less significant feature of the project at School B, where the teacher found that she had to maintain control to a large extent in order to manage behaviour. Whilst some students at School B took to the project and thrived (a group of girls playing Jingle Bells on chime bells came into the music room every lunchtime to rehearse, for example), most students achieved little without direction and overt structuring of their learning. The teacher attributed this partly to the culture of the school, which she felt encouraged students to expect directed learning rather than fostering independent learning skills. By contrast, both the other schools actively promote programmes that support independent approaches to learning across the curriculum.

\section{Sometimes we got things wrong}

A very high proportion of students felt that they got things wrong at times; although relatively few were motivated by this (Table 6), and few rated this as an important factor in helping them to learn (Table 7) - which is perhaps not surprising. It might be expected that there would be a direct relationship between the extent to which students made mistakes and the extent to which they were given control of their work and were required to be creative. However, this does not appear to be the case, because $91 \%$ of students at School B felt that they got things wrong, whilst only $54 \%$ of them felt in control of their work and $77 \%$ thought that they had to be creative. This suggests that the sense of getting things wrong might have been connected with feelings of not knowing how to go about the task required by the brief (ie. preparing a track for the class CD), an interpretation that is supported by the teacher's comments. She remarked that the demands of this project in terms of creative music making were significantly beyond the previous work carried out by the students in music lessons.

Indeed, all three teachers commented that less able students found this scheme of work difficult at times. The requirement to manage their own learning as well as to define their own musical task was a significant challenge for some students. This is reflected in the grades for the project, some students at Schools B and C attaining significantly lower marks than in the previous project (Table 8) (The grade system at School A did not recognise negative progress.) The teacher at School A made a point of supporting the less able students. He 
observed that the use of ICT, and Garage Band software in particular, provided excellent support for lower-achieving students. The possibility of using pre-composed material enabled them to engage with the task and achieve something that sounded musical, giving them a starting point for more original work. He also made a point of intervening to support groups that were struggling to manage their work by asking questions and providing a choice of solutions to problems. In this way he aimed to prevent students from disengaging with the task because they did not feel able to succeed at it, whilst avoiding removing from the students the responsibility of making their own decisions.

\section{I had to work out what I needed to learn to complete the task}

It is notable that students at School C felt strongly that they had to work out what they needed to learn, that this motivated them, and that this was the factor that was most important in helping them to learn. By contrast, most students at both Schools A and B ranked this as the least significant factor in their learning (Table 7); and at School B it was the feature of enterprise pedagogy that was least recognised by students.

Of the three teachers, the teacher at School C was the most structured in her approach to the scheme of work. She used the first two lessons to introduce the brief, giving students the opportunity to listen to music from computer games and to analyse what made it work. In doing so, she introduced the success criteria for the finished product, which she referred back to regularly as the project continued. In the lessons that followed, when students were developing their response to the brief, she prompted students to stop work in the middle and at the end of lessons to review their progress and set new targets. In this way, she actively supported the students in standing back from their work to consider what they needed to learn in order to make progress. The teacher at School A took a similar approach when introducing the brief, and supported the students in developing their own success criteria following their analysis of example promotional films. He noted, however, that when using enterprise pedagogy in a future project, he would take a more structured approach to target setting and managing interim deadlines.

\section{Different people in our group had different roles}

Most students considered that different people in their groups had different roles. Many students at Schools A and C were motivated by this (fewer at School B), but not many rated this as an important factor in contributing to their learning.

All three teachers felt that the diversity of roles required by their respective projects supported effective differentiation. Not only did the projects enable students to contribute to their group by taking on musical tasks that were appropriate to their ability, but students with strengths outside music were able to draw on these to support their musical learning. (For example, two girls at School B who were good at art took on the role of designing the CD cover.) In addition, the teacher at School A commented that students who sometimes struggle with the social aspect of group work in music were able to work alone on one element of the task which could then be integrated with the group's work.

However, all three teachers also felt that the diversity of roles within their projects presented challenges for assessment. The teacher at School A, for example, recognised that editing a film and discussing its musical implications demonstrated musical learning, just as recording the piano part to fulfil those implications demonstrated musical learning. Yet in assessing students' work he felt a tension between recognising musical understanding, enterprise skills 
(such as leadership) and other skills connected with the project (such as video editing). This points to the need for each student to have a musical role in their group's work (regardless of other roles they may have) as well as to the importance (noted by all three teachers) of monitoring and assessing the contribution made by students during the project, not just in the presentation of the final outcome.

\section{Conclusion}

This conclusion will first of all consider each of the research questions raised in relation to enterprise pedagogy. It will then consider some wider implications for enterprise pedagogy as one among multiple pedagogical approaches, together with some thoughts on further areas of research.

\section{To what extent did enterprise pedagogy motivate students to learn?}

A central feature of enterprise pedagogy was the use of a brief to set a musical task that would involve students in engaging with particular musical learning objectives. Many of the students in this study were motivated by the way in which this brief connected the musical task with their lives and required them to respond creatively in controlling the musical outcome. Limiting factors on motivation were the extent to which students believed themselves capable of fulfilling the brief and their ability to overcome musical and organisational difficulties along the way. It was found that these factors could be addressed successfully through the supporting role of the teacher.

What impact did enterprise pedagogy have on learning outcomes?

It is difficult to draw any firm conclusions, partly because of the short period of study and the relatively small number of students, but also because of the differences between the schools' assessment procedures. However, one feature to emerge was the potential for enterprise pedagogy to support the effective differentiation of learning. Not only did it give the more able students freedom to find their own limits within the task set by the brief, but it encouraged students of differing abilities to take different roles that played to their strengths. With appropriate support from the teacher, this made it possible for students of all abilities to engage in musical learning whilst making a positive contribution to their group's response to the brief.

To what extent were teachers able to implement practices promoting enterprise learning that were congruent with the underlying theories.

Whereas Harris (1991) found the effectiveness of enterprise learning to have been limited by the teacher's attitudes, perhaps the most interesting aspect of this study is the finding that the attitudes of both students and teacher needed to be congruent with the underlying theories of enterprise pedagogy for it to be effective. The questionnaire responses from students at School B suggest that their teacher successfully communicated the ethos of enterprise learning to them; and yet their unfamiliarity with the expectations and the skills required for independent learning inhibited their ability to respond to the teacher as she had expected them to. A greater degree of shared understanding about independent learning already existed at the other two schools, making it easier for the teachers to develop further the students' 
capacity for enterprise learning. Two specific practices emerged as important in promoting effective enterprise learning. One was the time devoted by teachers at the beginning of the project to exploring with the students the nature of the brief. This enabled students to develop their understanding of what was expected of them and to take ownership of the project. The other was the teacher's role in explicitly promoting skills associated with independent learning, such as the allocation of roles within groups and the setting of targets. Using enterprise learning within music was not simply a question of applying existing skills to the musical task, but of developing them further in the process of responding to the brief.

\section{Wider implications}

Enterprise pedagogy occupies a place on the menu of multiple pedagogies that is available to music teachers, alongside formal, informal and nonformal pedagogies. Each combines a selection of practices with the theories and values that underpin them to promote a particular form of learning. A teacher might select a particular form of pedagogy to teach a given topic to a given class at a given stage in their development, choosing the model of teaching and learning that is thought to be most effective in those circumstances. The key question is, to what extent an individual teacher or a particular class is capable of adjusting themselves to the variation in the theories and values of teaching and learning that underpin different models of pedagogy. For selecting from a range of practices is not sufficient: these practices need to be congruent with the underlying theories and values in order to be effective; and this study suggests that if a class does not share these underlying ideas, then they will need to be actively supported by the teacher in learning them if a pedagogical approach is to achieve its desired effect.

Further research might investigate the practical implications of working with multiple pedagogies, in particular the ability of teachers and students to adjust their pedagogical assumptions within a given timeframe (for example, whether it is realistic to change pedagogical model from term to term or whether doing so over longer periods is more effective). Research might investigate whether other models of musical pedagogy could usefully be defined. (A model of instrumental pedagogy, for example, might abstract the distinct practices of instrumental teaching and their underlying assumptions so that they could be applied to other contexts.) There is also a need for further analysis of how the practices and theories of different musical pedagogies overlap or are distinct. Connected with all of these concerns is the question of how the practices, theories and values of multiple pedagogies combine to enrich an individual teacher's evolving personal pedagogical identity over the longer term. 


\section{References}

Alexander, R. 2001. Border Crossings: Towards a comparative pedagogy Comparative Education 37 no 44: 507-523.

Alexander, R. 2008. Essays on pedagogy Abingdon: Routledge

Alexander, R., ed. 2010. Children, their world, their education: Final report of the Cambridge Primary Review Abingdon: Routledge

Black, P. 2001. Formative assessment and curriculum consequences. In Curriculum and assessment ed. D. Scott, 7-23. Westport: Ablex Publishing.

Bernstein, B. 1996. Pedagogy, symbolic control and identity, London: Taylor \& Francis

Cain, T. 2008. The characteristics of action research in music education British Journal of Music Education, 25:3, 283 - 313.

Cain, T. 2010. Music teachers' action research and the development of Big K Knowledge International Journal of Music Education, 28:2, 159 - 175.

DCSF 2007. The National Curriculum: Statutory requirements for key stages 3 and 4 London: Department for Children, Schools and Families

DCSF 2010. A guide to enterprise education London: Department for Children Schools and Families.

Edexcel. nd. Our history. http://www.edexcel.com/Aboutus/who-we-are/ourhistory/Pages/Ourhistory.aspx (Accessed 10 September 2011).

Edexcel. 2007. Specification for Edexcel Level 2 BTEC First Certificate and Edexcel Level 2 BTEC First Diploma in Music, Issue 2. http://www.edexcel.com/quals/firsts/pamusic/music/Pages/default.aspx (Accessed 14 July 2011).

Edexcel. 2010. Specification for Edexcel Diplomas Levels 1-2 in Creative and Media Principal Learning, Issue 3.

http://www.edexcel.com/migrationdocuments/Diploma/DP021031-Diploma-in-Creativeand-Media-L1-2-Phase-1-Issue-3-050510.pdf (Accessed on 10 September 2011).

Elliott, D. J. 1995. Music Matters: A new philosophy of music Oxford: Oxford University Press

European Parliament. 2006. Key competencies for lifelong learning: European reference framework. http://ec.europa.eu/dgs/education culture/publ/pdf/lllearning/keycomp_en.pdf (Accessed 22 February 2012)

Fautley, M. 2010. Assessment in music education Oxford: Oxford University Press.

Gordon, E.E. 1989. Learning sequences in music Chicago: GIA Publications Inc 
Green, L. 2008 Music, informal learning and the school. Alershot: Ashgate.

Harris, A. 1995. Teaching approaches in enterprise education: A classroom observation study. British Journal of Education and work. 8, no. 1: 49-58.

Johnson, C. 1988. Enterprise education and training British Journal of Education and Work 2, no. 1: 61-65.

Jones, B. \& Iredale, N. 2010 Enterprise education as pedagogy Education and Training 52, no. 1: 7-19.

Lave, J. \& Wenger, E. 1991. Situated peripheral participation Cambridge: Cambridge University Press.

Loughran, J. 2010. What expert teachers do Routledge: Abingdon

McNiff, J. 1988. Action research: Principles and practice Basingstoke: Macmillan

Moore, A. 2000. Teaching and Learning: Pedagogy, curriculum and culture London: Routledge Falmer

Ofsted. 2006. An evaluation of the Paul Hamlyn Foundation's Musical Futures Project http://www.ofsted.gov.uk/resources/evaluation-of-paul-hamlyn-foundations-musicalfutures-project (Accessed on 10 September 2011).

Pring, R. 2004. Philosophy of education research ( $2^{\text {nd }}$ Edition) London: Continuum

Schön, D.A. 1983. The reflective practitioner: How professinoals think in action London: Maurice Temple Smith Ltd

Shuttleworth, D. 1993. Enterprise learning in action London: Routledge.

Swanwick, K. 1999. Teaching music musically London: Routledge 